\title{
Teaching NeuroImage: Increasing SPECTations for Ictal SPECT in Epilepsy Surgical Evaluation
}

Fábio A. Nascimento, MD, Rory L. Cochran, MD, PhD, David Z. Chow, MD, James A. Scott, MD, and Catherine J. Chu, MD

Neurology ${ }^{\circledR}$ 2021;97:e647-e648. doi:10.1212/WNL.0000000000012097

Figure 1 Ictal EEG
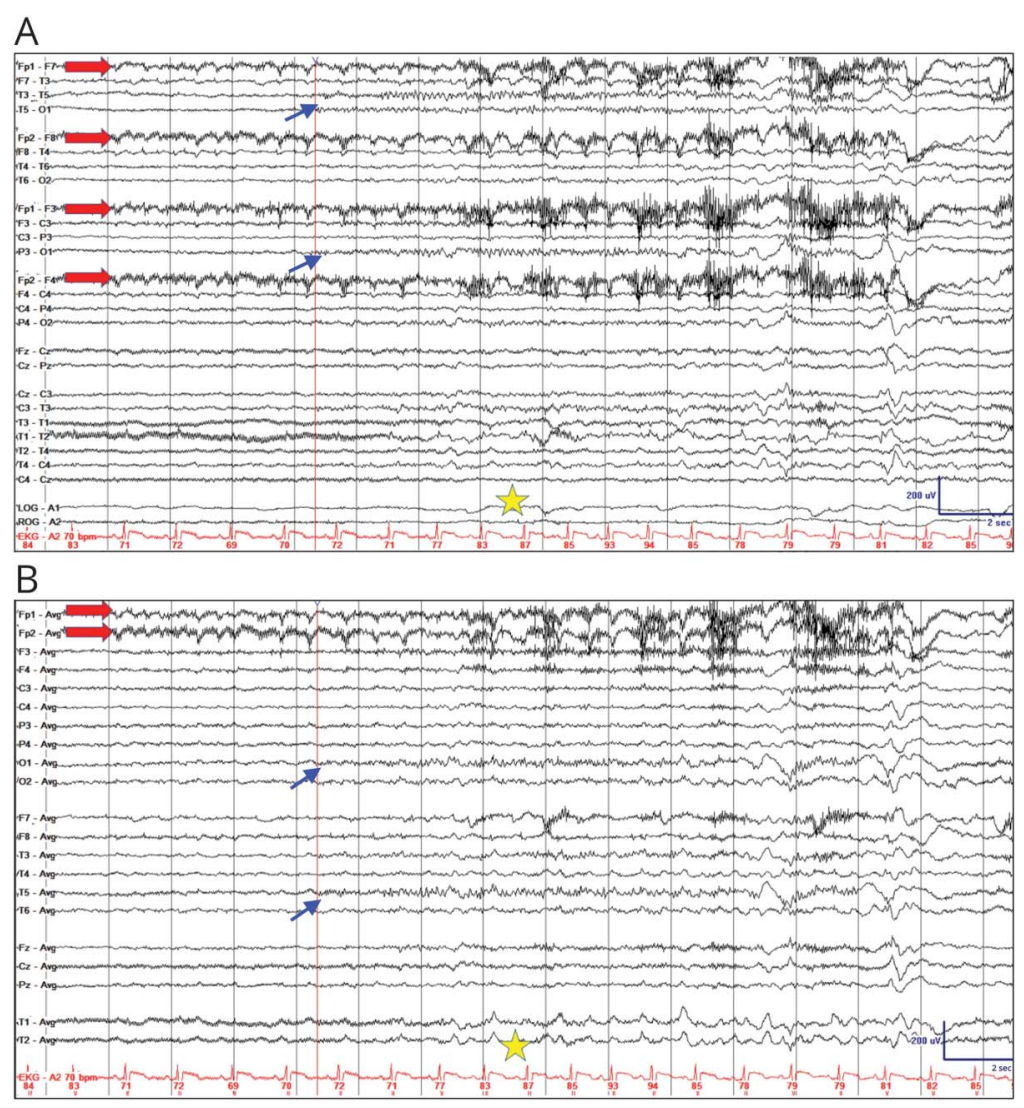

Sensitivity $10 \mu \mathrm{V} / \mathrm{mm}$, low-frequency filter $1 \mathrm{~Hz}$, high-frequency filter $70 \mathrm{~Hz}$, notch off. (A) Bipolar and (B) average reference showing initial eyelid fluttering artifact (red arrows) followed by $50 \mu \mathrm{V}, 10-12 \mathrm{~Hz}$ rhythmic activity at T5 and 01 (vertical red line and blue arrows). 99mTc-ECD was injected 3-4 seconds (star) after first unequivocal ictal electrographic change.

We report a 15-year-old boy with chromosome 19p13.3 microdeletion, intellectual disability, colobomas, and drug-resistant epilepsy. He had near daily seizures characterized by eyelid fluttering, behavioral arrest, and unawareness with occasional progression to generalized tonic activity. Brain MRI showed diffuse white matter hyperintensities with a predilection for subcortical U-fibers. Video-EEG monitoring showed multifocal interictal discharges but a consistent ictal onset grossly in the left posterior temporal and occipital regions but with up to 10 seconds of electroclinical delay. Brain PET was unremarkable, but ictal SPECT (figures 1 and 2) revealed a discrete functional lesion in the left ventral occipital cortex. Here, ictal SPECT delineated the 3D
Correspondence

Dr. Nascimento

nascimento.fabio.a@

gmail.com
MORE ONLINE

Teaching slides

http://links.lww.com/

WNL/B386 


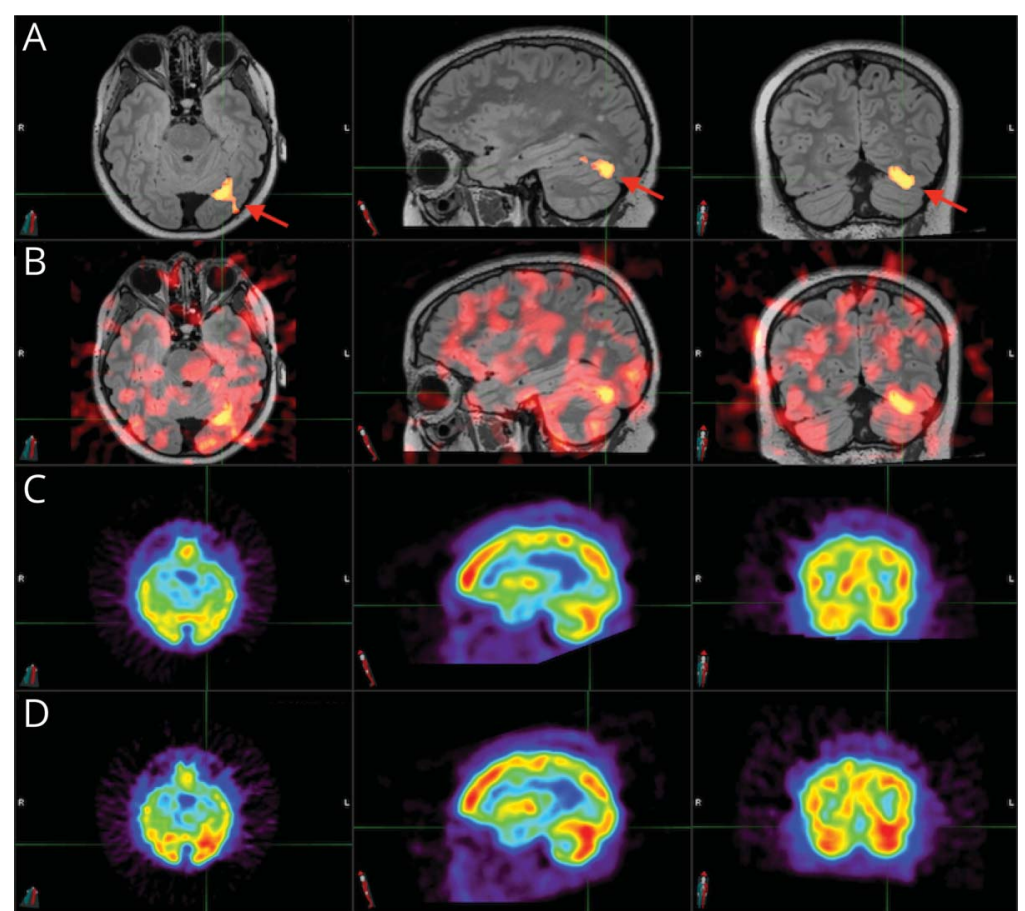

(A, B) A focus of hyperperfusion (red arrows) within the left ventral occipital cortex using fused subtraction SPECTSPACE fluid-attenuated inversion recovery MRI. (A) Adjusted to show differences with $Z$ scores $>2.5$; $(B)$ shows all differences. (C, D) Interictal and ictal phases of $99 \mathrm{mTc}-\mathrm{ECD}$ perfusion SPECT, respectively. borders of the seizure onset zone in the deep occipital cortex. This information can be used to further refine the epileptogenic zone (EZ) in a targeted stereo-EEG investigation to optimize surgical outcome ${ }^{1}$ and decrease SUDEP risk. ${ }^{2}$

Ictal SPECT may assist lateralization, and even localization, of the EZ in patients with occipital lobe epilepsy ${ }^{3,4}$; MRI coregistration and early injection may further increase its yield.

\section{Study Funding}

No targeted funding reported.

\section{Disclosure}

F. Nascimento is a member of the Neurology ${ }^{\circledR}$ Resident \& Fellow Section Editorial Team. R. Cochran, D. Chow, J. Scott, and $\mathrm{C}$. Chu report no disclosures relevant to the manuscript. Go to Neurology.org/N for full disclosures.

\section{Appendix Authors}

\begin{tabular}{|c|c|c|}
\hline Name & Location & Contribution \\
\hline $\begin{array}{l}\text { Fábio A. } \\
\text { Nascimento, } \\
\text { MD }\end{array}$ & $\begin{array}{l}\text { Massachusetts } \\
\text { General Hospital, } \\
\text { Boston }\end{array}$ & $\begin{array}{l}\text { Study concept and design, data } \\
\text { analysis and interpretation, } \\
\text { drafting manuscript }\end{array}$ \\
\hline
\end{tabular}

\section{Appendix (continued)}

\begin{tabular}{lll}
\hline Name & Location & Contribution \\
\hline $\begin{array}{l}\text { Rory L. } \\
\text { Cochran, MD, } \\
\text { PhD }\end{array}$ & $\begin{array}{l}\text { Massachusetts } \\
\text { General Hospital, } \\
\text { Boston }\end{array}$ & $\begin{array}{l}\text { Data analysis and interpretation, } \\
\text { drafting manuscript }\end{array}$ \\
\hline $\begin{array}{l}\text { David Z. } \\
\text { Chow, MD }\end{array}$ & $\begin{array}{l}\text { Massachusetts } \\
\text { General Hospital, } \\
\text { Boston }\end{array}$ & $\begin{array}{l}\text { Data analysis and interpretation, } \\
\text { revising manuscript }\end{array}$ \\
\hline $\begin{array}{l}\text { James A. } \\
\text { Scott, MD }\end{array}$ & $\begin{array}{l}\text { Massachusetts } \\
\text { General Hospital, }\end{array}$ & $\begin{array}{l}\text { Data analysis and interpretation, } \\
\text { revising manuscript }\end{array}$ \\
\hline $\begin{array}{l}\text { Catherine J. } \\
\text { Chu, MD }\end{array}$ & $\begin{array}{l}\text { Massachusetts } \\
\text { General Hospital, } \\
\text { Boston }\end{array}$ & $\begin{array}{l}\text { Data analysis and interpretation, } \\
\text { revising manuscript, final approval }\end{array}$ \\
\end{tabular}

\section{References}

1. Widjaja E, Jain P, Demoe L, et al. Seizure outcome of pediatric epilepsy surgery: systematic review and meta-analyses. Neurology. 2020;94(7):311-321.

2. Devinsky O, Hesdorffer DC, Thurman DJ, Lhatoo S, Richerson G. Sudden unexpected death in epilepsy: epidemiology, mechanisms, and prevention. Lancet Neurol. 2016;15(10):1075-1088.

3. Sturm JW, Newton MR, Chinvarun Y, Berlangieri SU, Berkovic SF. Ictal SPECT and interictal PET in the localization of occipital lobe epilepsy. Epilepsia. 2000; 41(4):463-466.

4. Kim SK, Lee DS, Lee SK, et al. Diagnostic performance of [18F]FDG-PET and ictal [99mTc]-HMPAO SPECT in occipital lobe epilepsy. Epilepsia. 2001;42(12) 1531-1540. 


\section{Neurology}

\section{Teaching NeuroImage: Increasing SPECTations for Ictal SPECT in Epilepsy Surgical Evaluation}

Fábio A. Nascimento, Rory L. Cochran, David Z. Chow, et al.

Neurology 2021;97;e647-e648 Published Online before print April 26, 2021

DOI 10.1212/WNL.0000000000012097

This information is current as of April 26, 2021

Updated Information \&
Services

References

Subspecialty Collections

Permissions \& Licensing

Reprints including high resolution figures, can be found at: http://n.neurology.org/content/97/6/e647.full

This article cites 4 articles, 1 of which you can access for free at: http://n.neurology.org/content/97/6/e647.full\#ref-list-1

This article, along with others on similar topics, appears in the following collection(s):

All clinical neurophysiology

http://n.neurology.org/cgi/collection/all_clinical_neurophysiology

SPECT

http://n.neurology.org/cgi/collection/spect

SPECT in epilepsy

http://n.neurology.org/cgi/collection/spect_in_epilepsy

Information about reproducing this article in parts (figures,tables) or in its entirety can be found online at:

http://www.neurology.org/about/about_the_journal\#permissions

Information about ordering reprints can be found online:

http://n.neurology.org/subscribers/advertise

Neurology ${ }^{\circledR}$ is the official journal of the American Academy of Neurology. Published continuously since 1951, it is now a weekly with 48 issues per year. Copyright () 2021 American Academy of Neurology. All rights reserved. Print ISSN: 0028-3878. Online ISSN: 1526-632X.

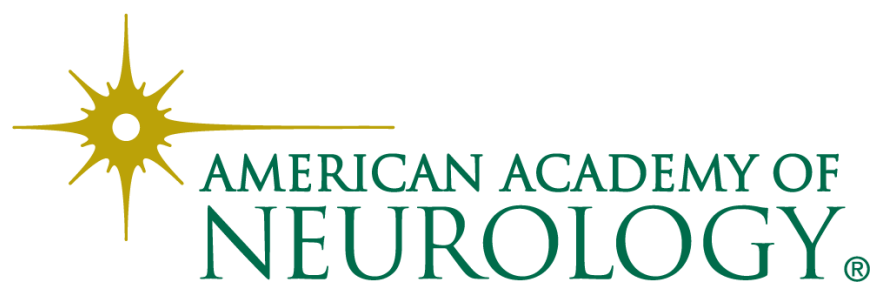

